International Journal of Heritage, Tourism and Hospitality Vol. (12), No. (2/2), September, 2018 By: Faculty of Tourism and Hotels, Fayoum University, Egypt

\title{
Effect of Applying Blue Ocean Strategy on Marketing Performance in the Egyptian Travel Agents
}

Ahmed Erfan Eltobgy Yasmeen Abd Elmoaty

Higher Institute of Tourism and Hotels, E.G.O.T.H Ismailia

\begin{abstract}
The research aims to; examine the effect of applying the Blue Ocean Strategy on the marketing performance measurement dimensions in the Egyptian travel agents. The quantitative - qualitative approaches were incorporated in this research. Data was collected from the managers and executives in marketing and tour operating departments in 60 Egyptian travel agents in Cairo through using a questionnaire form. Personal Interviews were conducted to help these agents better understanding this new strategy. The obtained data for this study, was presented in tables comprising of mean, standard deviation, and Friedman's test, while the hypotheses was tested using, simple liner regression and ANOVA analysis at a significance level of 5\% with the aid of statistical package for social sciences (SPSS version 22). The findings revealed that Blue Ocean Strategy has a positive significant effect on marketing performance dimensions in the Egyptian travel agent. Blue Ocean Strategy is considered a quite dynamic process as it affects market shares, customer satisfaction, customer loyalty and innovation. The research was finally concluded by raising recommendations for improvement the BOS implications in the Egyptian travel agents, in order to increase its marketing performance.
\end{abstract}

Keywords: Blue Ocean Strategy, Marketing performance, Marketing myopia, uncontested market, Travel agents.

\section{Introduction}

Travel agents play a central role in the tourism industry. As intermediates between tourists and tourism businesses, they can influence the choice of consumers, practices of suppliers and the development within destinations (www. Travelife.com). On the other hand, despite the great growth in the tourism industry, the advancement of technologies is challenging these traditional intermediaries. The tourism and travel industries suppliers such as airlines and hotels are always connected to their customers directly, so the traditional travel agents are negatively affected through these issues, as their markets are declining (Konar \& Kumar, 2016). From this point of view, travel agents in today's highly opportunities and fiercely competitive tourism marketing environment, must develop its orientations, through different strategies in order to compete and increase its marketing performance. One of these new strategies that can enhance the organizational marketing performance, especially market share and customer satisfaction, is the Blue Ocean Strategy (Okechukwu et al., 2018). Many researches shed light on the Blue Ocean Strategy and its influence in organizations in general. BOS enables organizations to think and create innovation to gain a vast opportunity for growth that is both profitable and rapid (Alam and Islam, 2017). This theory try to create a prance in value for the organization, its buyers, and its employees while unlocking new demand and making the competition irrelevant ( Kim and Mauborgne, 2017). Based on the importance of this strategy, this research aims to define and design a Blue Ocean Strategy framework for the Egyptian travel agents, and identify the effect of applying this framework on the their marketing performance.

\section{Previous Studies}

BOS Implementation Cases and Effect 
BOS has been handled by many researches as a new marketing strategy for organizations in different sectors to create uncontested market in which competition irrelevant (Kim and Mauborgne, 2004, 2005a, 2005b; Srinivasan, 2006; kumar, 2008). BOS has been successfully defined and applied in organizations in different sectors, table (1) summarizes examples of these sectors. Sectors are alphabetically ordered.

Table 1: Organizations in different sectors succeed in applying BOS

\begin{tabular}{|c|c|c|}
\hline Sector & Writers / researchers & Remarks \\
\hline $\begin{array}{c}\text { Airline } \\
\text { Companies }\end{array}$ & Kabukin, 2014 & $\begin{array}{l}\text { Researcher indicates that South West } \\
\text { Airlines (SW Airlines) which is considered } \\
\text { as a low-cost carrier in USA, created a blue } \\
\text { ocean by offering the speed of air travel } \\
\text { with more flexibility of driving and lower } \\
\text { cost. }\end{array}$ \\
\hline \multirow[t]{2}{*}{ Banking } & Motley, 2008 & $\begin{array}{l}\text { Researcher applied BOS to bank industry } \\
\text { and defined its positive impact on } \\
\text { operations cost reduction which contributes } \\
\text { in increasing profits }\end{array}$ \\
\hline & Wanless, 2009 & $\begin{array}{l}\text { Researcher studied a case of a bank Pender } \\
\text { Financial Group illustrated that using BOS, } \\
\text { creates a new market space and makes its } \\
\text { processes more profitable. }\end{array}$ \\
\hline $\begin{array}{c}\text { Health } \\
\text { services }\end{array}$ & Kang \& Li, 2013 & $\begin{array}{l}\text { Researchers studied applying BOS to help } \\
\text { 'Jiankang Clinic' in Sweden to create } \\
\text { competitive advantages, the study pointed } \\
\text { out that the product innovation and } \\
\text { promotion improvements are important for } \\
\text { the clinic strategic planning. }\end{array}$ \\
\hline \multirow[t]{2}{*}{$\begin{array}{c}\text { Higher } \\
\text { Education }\end{array}$} & $\begin{array}{c}\text { Savage \& Bommels, } \\
2008\end{array}$ & $\begin{array}{l}\text { Researchers explained how to support } \\
\text { innovation by applying the BOS in medical } \\
\text { education in Sweden. }\end{array}$ \\
\hline & Braganca, 2016 & $\begin{array}{l}\text { Researcher discussed the necessity of } \\
\text { applying the strategy in the field of higher } \\
\text { education in United Arab Emirates in order } \\
\text { to attain competitive advantages. }\end{array}$ \\
\hline \multirow[t]{2}{*}{ Hotels } & Yang, 2012 & $\begin{array}{l}\text { Researcher identified the attributes of BOS } \\
\text { in selected hotels in Taiwan. The results } \\
\text { showed that the more brand expansion is } \\
\text { enacted through applying BOS, the more } \\
\text { new customer value is created. } \\
\text { Furthermore, creating value to hotel } \\
\text { offerings would reinforce the revenue } \\
\text { management and strengthen the market } \\
\text { position in the hotel market space. }\end{array}$ \\
\hline & Zahri et al., 2015 & $\begin{array}{l}\text { Researchers examined the BOS tools and } \\
\text { frameworks from hotel industry's } \\
\text { perspectives. In this study, the researchers } \\
\text { proved the impact of implementing this } \\
\text { strategy on increasing hotel financial } \\
\text { performance in Malaysia. }\end{array}$ \\
\hline Information & Alam \& Islam, 2017 & Researchers indicated that Google used the \\
\hline
\end{tabular}


International Journal of Heritage, Tourism and Hospitality Vol. (12), No. (2/2), September, 2018 By: Faculty of Tourism and Hotels, Fayoum University, Egypt

\begin{tabular}{|c|c|c|}
\hline $\begin{array}{c}\text { Based } \\
\text { Companies }\end{array}$ & & $\begin{array}{l}\text { main tools of BOS to innovate products and } \\
\text { services }\end{array}$ \\
\hline $\begin{array}{l}\text { Insurance } \\
\text { Companies }\end{array}$ & Jedil et al., 2015 & $\begin{array}{l}\text { Researchers examined the effects of BOS } \\
\text { in Sina Insurance Company in Iran. The } \\
\text { obtained results showed that the } \\
\text { implementation of BOS contributes } \\
\text { positively in increasing their } \\
\text { competitiveness. }\end{array}$ \\
\hline Retailing & Burke et al., 2016 & $\begin{array}{l}\text { Researchers investigated the nature of the } \\
\text { competition process in Dutch retailing } \\
\text { sector by constructing BOS. }\end{array}$ \\
\hline $\begin{array}{l}\text { Technology } \\
\text { Based } \\
\text { Companies }\end{array}$ & Alam \& Islam, 2017 & $\begin{array}{l}\text { Researchers identifies a series of blue } \\
\text { ocean strategic moves at Apple, Inc. that } \\
\text { transformed the company from a computer } \\
\text { manufacturer into a consumer electronics } \\
\text { giant. }\end{array}$ \\
\hline \multirow[t]{2}{*}{$\begin{array}{c}\text { Telecommunic } \\
\text { ation }\end{array}$} & Alghamdi, 2016 & $\begin{array}{l}\text { Researcher analyzed the positive } \\
\text { correlation between market knowledge and } \\
\text { BOS in achieving competitive advantage in } \\
\text { Saudi Telecom Company }\end{array}$ \\
\hline & Zhao \& Jinwei, 2011 & $\begin{array}{l}\text { Researchers demonstrated this new strategy } \\
\text { application in Chinese } 3 \mathrm{G} \text { Mobile Telecom } \\
\text { Industry, and they found that BOS will help } \\
\text { Chinese mobile operators to enhance their } \\
\begin{array}{l}\text { competitiveness and capture new } \\
\text { customers. }\end{array}\end{array}$ \\
\hline Travel agents & $\mathrm{Li}, 2018$ & $\begin{array}{l}\text { The researcher only indicates the necessity } \\
\text { of applying BOS in Chinese tourism } \\
\text { companies. }\end{array}$ \\
\hline
\end{tabular}

After reviewing previous studies, researchers found that there has been a lack of attention among the researchers in applying the BOS in tourism sectors in general and travel agents in particular. Therefore, this study is intended to contribute to filling this gap through defining this strategy principles and discussing its tools and frameworks.

\section{Research Problem}

In this highly opportunities and fiercely competitive tourism market environment, while traditional competition-based strategies (Red Ocean Strategies) are necessary, they are not sufficient to sustain high performance or to survive at least. Travel agencies have to adopt other strategies such as Blue Ocean Strategy, which is considered one of the intellectual contributions and modern marketing strategy used by agent to pull itself out of this powerful and fierce (bloody) market competition. This strategy provides a systematic way to create demands and improve the value of the travel agent ( $\mathrm{Li}, 2018)$.

From this point of view, the researchers conducted an exploratory research with managers and executives in marketing and tour operating departments in Egyptian travel agents, in order to clarify the research problem. They found that the competition is based on Porter's Generic Competitive Strategies, which leads the whole industry to the price war. The researchers also found that the majority of these agents suffer from marketing myopia, because they are so taken with the existing tourists wants and lose sight of underlying the new tourists' needs. They are exposed 
to threat, delay in growth and eventually leaving the market. Most of the Egyptian travel agents also have a lack in attaining tools for creating competitive markets in which other entities cannot compete with them, at least in the short term, and this finding is in line with other researchers opinion (Fawzy and Qoura, 2016).

Based on these problems, the following questions are constructed:

- How the Egyptian travel agents can go beyond competing, seize new profit and growth opportunities?

- How the Egyptian travel agents can acquire new marketing strategies like BOS and create uncontested market space?

- How the Egyptian travel agents can measure their marketing performance and find ways to increase it

\section{Research Objectives}

This research seeks to achieve the following objectives:

1. Explain Blue Ocean Strategy, define marketing performance, and determine its measurement dimensions.

2. Design a BOS framework ('As Is' strategy canvas, 'Eliminate - Reduce - Raise Create Grid', and 'To Be' strategy canvas) for the Egyptian travel agent, in order to create uncontested market space and change the focus from the current competition to creation of innovative value and demand.

3. Identify the effect of the implementation of the previous BOS tools in the Egyptian travel agents on their marketing performance.

4. Raise recommendations for improvement the BOS implications in the Egyptian travel agents, in order to increase its marketing performance.

\section{Research Hypothesis}

Drawing from the previous perspectives, researchers build the following hypothesis:

1. Applying the BOS, has significant effect, on the Egyptian travel agents' marketing performance.

\section{Research Limitation}

Researchers have limitation concerns the research population, which is dictated by the type of the research problem. The research population includes only the top 10 travel agents and large travel agents with separate marketing department (Category A, in Cairo).

\section{Literature Review}

\section{Blue Ocean Strategy}

The rapid pace of innovation and change in business environment nowadays, has led researchers and executives to search a strategy that is more dynamic to enhance organizational performance in general (Okechukwu, 2018). By this way, a new business strategy named "Blue Ocean Strategy" has been developed by Kim \& Mauborgne (2004). They clarify that this strategy helps organizations to get relief of being trapped in traditional markets through focusing on attracting new customers, understand market creation, stop focusing on price based competition, and worry less about segmentation. According to this strategy, the market universe is descried by the metaphor of Red and Blue Ocean (Kim \& Mauborgne, 2005a). In the red ocean, industry boundaries are defined and accepted, and the competitive strategies are known. Organizations in Red Ocean try to outperform their emulator to grab a greater share of product or service demand. As the market space gets packed, opportunities of 
profits and growth are reduced, and competition turns the ocean bloody; hence, the term Red Ocean is used (Alam and Islam, 2017).

A Blue Ocean, in contrast, symbolizes all the aspects of specific industry which are not in existence today the unknown market space. This market is untainted by competition. In Blue Ocean, demand is created rather than fought over. In Blue Ocean, competition is irrelevant because the competitive strategies are waiting to be set. Blue Ocean is an analogy to describe the wider, deeper potential of market space that is not yet explored. The main principle of the BOS is to rebuild market borders to eliminate competition (Butler, 2008 ; Jussani et al., 2010). Table (2) shows Red Ocean Strategy characteristics versus Blue Ocean ones.

Table 1: Red Ocean Strategy versus Blue Ocean Strategy

\begin{tabular}{|l|l|}
\hline \multicolumn{1}{|c|}{ ROS } & \multicolumn{1}{|c|}{ BOS } \\
\hline Complete in existing market place & Create uncontested market place \\
\hline Beat the competition & Make the competition irrelevant \\
\hline Exploit existing demand & Create and capture new demand \\
\hline Make the value-cost trade-off & Break the value-cost trade-off \\
\hline $\begin{array}{l}\text { Align the whole system of an } \\
\text { organization's activities, with its strategic } \\
\text { choice of differentiation or low cost }\end{array}$ & $\begin{array}{l}\text { Align the whole system of an } \\
\text { organization's activities, with its strategic } \\
\text { choice of differentiation and low cost }\end{array}$ \\
\hline
\end{tabular}

Source: (Basri et al., 2011)

Kim and Mauborgne (2005b) and Brady (2005) notes that Blue Ocean Strategy depends on the value innovation which includes any actions can drive costs down for the organizations, while driving the value up for customers asshown in figure (1).

Figure 1: Value Innovation in Blue Ocean Strategy

Red Ocean Approach

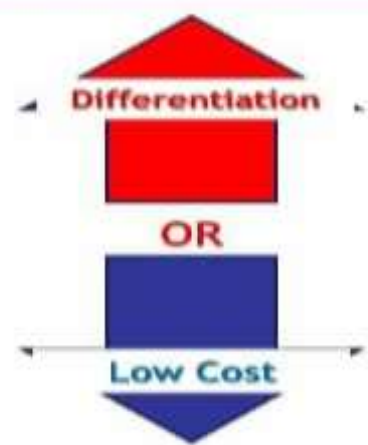

Source: Kim and Mauborgne (2005b)
Blue Ocean Approach

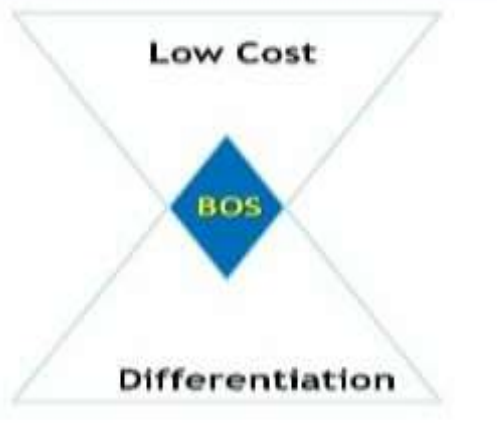

\section{Blue Ocean Strategy Principles}

Researchers identify the main principles that can create a Blue Ocean. They found that they must analyze the industry and market needs, in order to detect customer needs that are not served yet. After finding a promising proposition, it needs to be honed by decreasing or removing dispensable parts as well as improving operations and adding reforms (Kim and Mauborgne, 2005). These principles can be achieved through the following tools.

\section{Blue Ocean Strategy Tools}

BOS is considered a four-step process with different analytical tools created by Kim \& Mauborgne (2004). This process presents a visual exploration to unlock people's 
creativity for driving the agent's strategy towards a blue ocean. The four major steps which can be applied in travel agents are:

1- Compare the travel agent businesses with competitors by drawing 'As Is' strategy canvas. Then discover where the travel agent strategy canvas needs to change (kim et al., 2007). 'As Is' strategy canvas is a major diagnostic and action framework tool shows the present business situation (Sheehan \& Vaidyanathan, 2009). The strategy canvas has two axes, a horizontal axis and a vertical one. The horizontal axis on the strategy canvas indicates the factors that an industry competes on and invests in. On the other hand, the vertical axis indicates the offering level of these key competing factors. Agents have to identify the factors of competition, evaluate the competition, and then chart the strategy canvas (Buchness, 2015).

2- Through field study, agent must observe the distinctive advantages of alternative products and services, then decide which elements should be eliminated, reduced, raised, and created. This four actions framework tries to complete a strategic tool called 'Eliminate - Reduce - Raise - Create Grid'. Through this matrix, agent try to answer the following questions:

Table 3: The Blue Ocean Grid

\begin{tabular}{|l|l|}
\hline $\begin{array}{l}\text { Eliminate } \\
\text { Which factors that the industry has } \\
\text { long competed on should be } \\
\text { eliminated? }\end{array}$ & $\begin{array}{l}\text { Reduce } \\
\text { What factors can be reduced? }\end{array}$ \\
\hline $\begin{array}{l}\text { Raise } \\
\begin{array}{l}\text { What factors should be raised above } \\
\text { the industry's standard? }\end{array}\end{array}$ & $\begin{array}{l}\text { Create } \\
\text { Which factors should be created that } \\
\text { the industry has never offered? }\end{array}$ \\
\hline
\end{tabular}

Source: (Papazov and Mihaylova, 2016)

3- Draw agent 'To Be' strategy canvas based on the previous insights from field observations.

4- Support the operational moves that allow the agent to actualize the new strategy (Kim et al., 2009).

Marketing performance

Nowadays, successful travel agencies are increasingly investing in marketing in order to differentiate their presented services and products from competitors and to resist price pressure (Huang, 2013). Marketing investments and efforts which are made by these gents, aims to build their brand image increase the visibility of their offerings, support customer loyalty and in general to enhance their performance (Mintz \& Currim, 2013). Moreover, some researchers found that, travel agents may be able to reinforce their competitive position and may be better equipped to handle the effect of the current crisis, by increasing their marketing expenditures (Alonso-Almeida \& Bremser, 2013). Considering the importance of travel agents marketing performance, allocating marketing resources efficiently and effectively among a wide range of programs is a difficult issue. Therefore, agents must carefully measure and evaluate their marketing performance and how marketing contributes to reaching the firm's goals. Marketing performance can be defined simply as the effectiveness and efficiency of an organization's marketing activities ( Bruni, et al., 2017).

Measuring marketing performance in travel agents is not considered as a new issue (Yilmaz \& Bititci, 2006). Nevertheless, agents haven't developed yet an appropriate measurement system, balancing financial and non-financial performance indicators. Leading travel agents are making efforts to design Marketing Performance Measurement Systems (MPMSs) that can provide them with timely feedback on 
marketing strategy implementation (Homburg et al., 2012). Early work on the measurement of marketing performance focused mainly on the financial measures of profit, sales (unit and value) and cash flow. But there is some unease about the use of financial measures to assess business performance. So, there was a move from the use of financial to non-financial measures of output. Newer, non-financial measures of output, such as customer satisfaction, customer loyalty, and brand equity have attracted considerable research interest. Researchers also recognized the growing importance of non-financial measures of performance in the emphasis of the fact that intangible assets, such as brand, technology, competence and customer loyalty, have gradually become more important measures of corporate performance. Most researchers identify other nonfinancial measures, these measures besides brand equity, include: market share, customer satisfaction, customer loyalty and innovation (Yuhui, 2010).

\section{Methodology}

The analytical descriptive approach was applied in this research, whose tools and methods described the study quantitatively and qualitatively. The empirical part of this study is based on a survey research that provides quantitative or numerical descriptions of attitudes and opinions of the target population through studying a sample of this population. The methodological tool chosen for the investigation in the Egyptian travel agent is a questionnaire.

\section{Research Measures}

The research is constructed with two phases. The first phase, researchers tried to present a BOS framework for the Egyptian travel agents. This phase including measures of traditional competitiveness factors in Egyptian travel agents, which was constructed to design the 'As Is' Egyptian travel agents BOS canvas. The construct was measured using 7 factors. These factors were developed from the Michael Porter's three generic competitive strategies: cost leadership, differentiation and focus (Porter, 1980). This phase was ended by introducing the four actions BOS framework 'Eliminate - Reduce - Raise - Create Grid'.

The second phase included measures of BOS elements on the Egyptian travel agents which were drawn from the four actions framework 'Eliminate - Reduce - Raise Create' which is based on the first phase results and insights from the field observations. This phase also include identifies the effect of these elements on the agents marketing performance. (Yuhui, 2010) clarify non-financial measures for the marketing performance, which were applied in this research. The researchers applied four measures including: market share, customer satisfaction, customer loyalty and innovation. All multiple item measures were assessed on a 5 point Likert-type scale, ranging from (1) strongly disagree to (5) strongly agree.

\section{Sampling}

According to The Egyptian Travel Agents Association, the number of travel agents (Category A) in Egypt is 2421 in 2017, Cairo has $70 \%$ of these agents which is about 1694 agents. The researchers depend on the purposive sample which is a nonprobability sample that is selected based on characteristics of a population and the problem and the objectives of the study. The researchers choose a purposive sample of 60 travel agents in order to assure that the results are valid and reliable, and affirm the possibility of applying this new strategy. the purposive sample includes managers and executives in marketing and tour operating departments in these travel agents 
(only the top 10 travel agents and large travel agents with separate marketing department). The sample size is 115 managers and executives from 60 travel agents. In the first phase, 103 complete questionnaires were received, representing a response rate of $89.5 \%$. The questionnaire forms were distributed and collected from the investigated sample during period from February - March 2018. For the second phase which researcher investigate the effect of applying the BOS grid elements on the agents' marketing performance, only 100 complete questionnaires were received, representing a response rate of $87 \%$. The questionnaire forms were distributed and collected by hand to the investigated sample during period from May - July-2018.

\section{Data analysis}

The researchers use both descriptive and inferential statistic to test the research hypothesis and determine the effect of applying the presented BOS in the Egyptian travel agents on its marketing performance. Mean scores, standard deviations and Friedman Test are calculated for all factors in the research. Liner regression and ANOVA analysis at a significance level of 5\% are used to find relationships and predict the value of each dependent variable (marketing performance dimensions: market share - customer satisfaction - customer loyalty - innovation) based on the value of applying the independent variables (BOS elements: eliminate - reduce - raise - create). The collected data were analyzed using the statistical package for social science (SPSS version 22).

First phase: Applying BOS Analytical Tool in the Egyptian Travel Agents:

1. Preliminary research which was conducted on 60 Egyptian travel agents in Cairo to identify their main competitiveness factors in the market as a first step in applying the strategy, which will help in comparing a specific travel agent with its competitors. Table (4) outlines the results of this step.

Table 4: Preliminary research results of the studied travel agents competitiveness factors before applying BOS elements

\begin{tabular}{|l|c|}
\hline \multicolumn{1}{|c|}{ competitiveness factors } & Percentage of agreements \\
\hline 1. Program cost reduction & $80 \%$ \\
\hline 2. Total program price reduction & $94 \%$ \\
\hline 3. Increase service quality & $43 \%$ \\
\hline 4. Differentiate programs & $50 \%$ \\
\hline 5. Differentiate segmentations & $52 \%$ \\
\hline 6. Differentiate marketing tools & $30 \%$ \\
\hline 7. Focus on special programs and segments & $12 \%$ \\
\hline
\end{tabular}

The previous data were applied in constructing the "As Is" strategy canvas which illustrates the present business situation for the Egyptian travel agents as shown in figure (2). 
International Journal of Heritage, Tourism and Hospitality Vol. (12), No. (2/2), September, 2018 By: Faculty of Tourism and Hotels, Fayoum University, Egypt

Figure 2: "As Is" Strategy Canvas for Egyptian travel agents

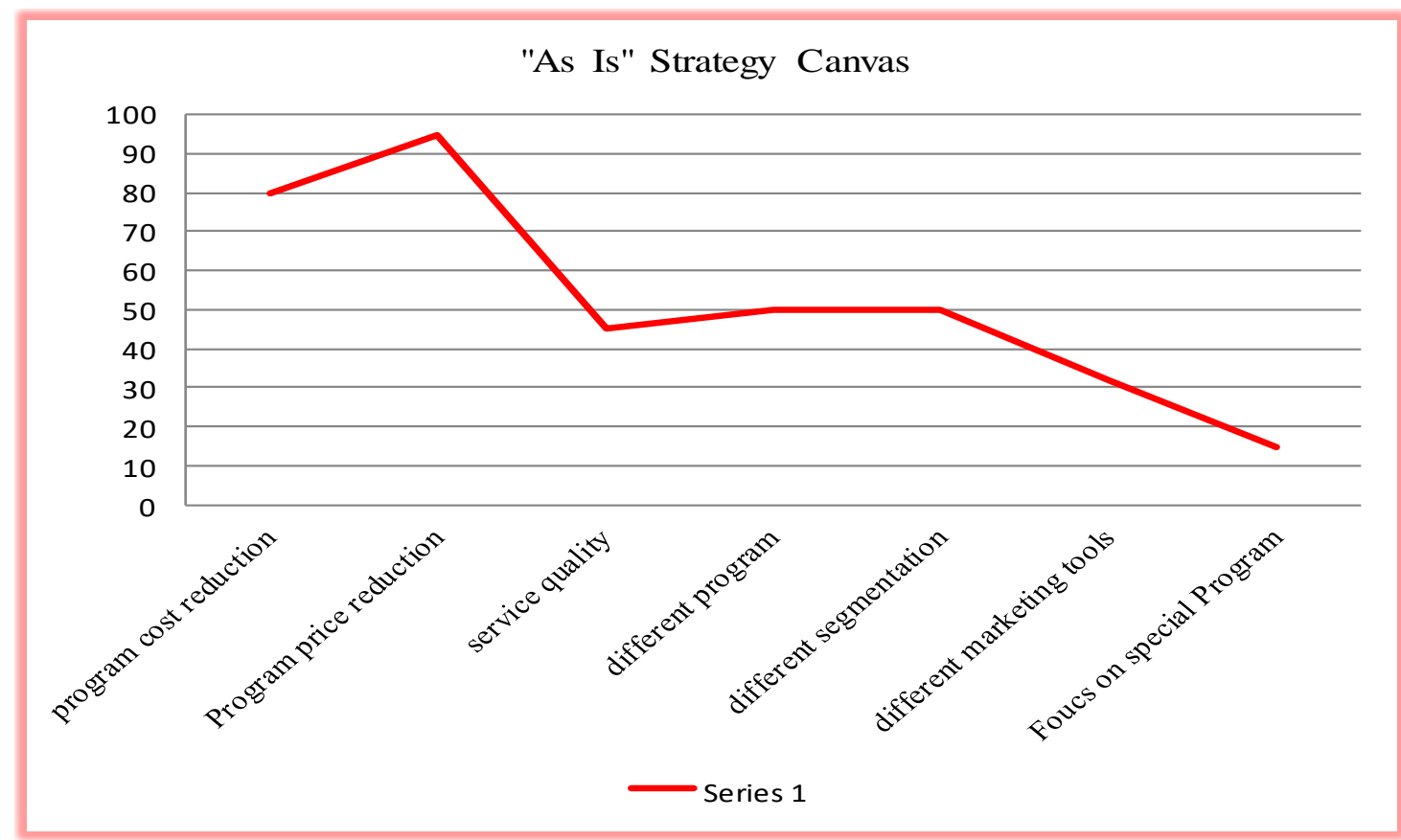

2- The term "Blue Ocean" was clarified to the interviewees in the selected agents, and open-ended questions were developed to guide semi-structured interviews. Participants were encouraged to develop and extend their thinking to complete step two which concerns about making the 'Eliminate - Reduce - Raise - Create Grid'. The four interviews questions which were drawn from Kim and Mauborgne (2005) are:

2-1 which factors that the agent takes for granted should be eliminated?

2-2 which factors should be reduced?

2-3 which factors should be raised?

2-4 which factors that the agent has never offered should be created?

Researchers present the elements which the agents may create or deal with, and those which should be reduced or eliminated. Researchers indicate how can the travel agent reconstruct the tourist value elements as shown in table (5) and present "To Be" Strategy Canvas.

Table 5: 'Eliminate-Reduce-Raise-Create Grid' for the studied travel agents

\begin{tabular}{|l|l|}
\hline \multicolumn{1}{|c|}{ Eliminate } & $\begin{array}{l}\text { Reduce } \\
\text { - Eliminating Price based competition. }\end{array}$ \\
- Eliminating frequent issues that face the clients \\
$\begin{array}{l}\text { by attempting to find permanent solutions for } \\
\text { them. }\end{array}$ & $\begin{array}{l}\text { Reducing the Participation in tourism } \\
\text { activities. }\end{array}$ \\
- Eliminating contracts with suppliers who did & $\begin{array}{l}\text { Reducing the concentration on the traditional } \\
\text { entertainment tourism programs. }\end{array}$ \\
not show a quality level consistent with the & $-\begin{array}{l}\text { Reducing the tourism activities that may harm } \\
\text { the environment or the local community in }\end{array}$ \\
needs of clients. & $\begin{array}{l}\text { order to be distinguished from other } \\
\text { - Eliminating some of the recurrent marketing } \\
\text { expenses associated with highly competitive } \\
\text { tourist markets. }\end{array}$ \\
$\begin{array}{l}\text { Reducing the low quality services that do not } \\
\text { achieve client satisfaction or add a value to the } \\
\text { client. }\end{array}$ \\
\hline $\begin{array}{l}\text { Raise } \\
\text { Enhancing the usage of web 2.0 applications in } \\
\text { improving customer relationship managements. } \\
\text { Most of the Egyptian travel agents use web 2.0 }\end{array}$ & $\begin{array}{l}\text { Create } \\
\text { Supporting the environment-based competitive } \\
\text { advantages which can make } \\
\text { differentiation to lead a higher market share and }\end{array}$ \\
\hline
\end{tabular}


applications in order to dissemination of information about their services and programs to customers. Web 2.0 applications can be used as a tool for forming online customer communities, enhancing customer satisfaction through product improvements and solving problems, monitoring the image and reputation of the agent, and also obtaining market intelligence. For example, through social networks, marketers in travel agents can learn more about customer experience; identify new trends and marketing opportunities, receiving early warnings about problems facing customers from online reviews.

- Increasing interest in the agent's brand.

- searching for internet brand strategy that may support them in creating distinctiveness through engaging their customers. Successful internet branding relay on targeting customers with unique messages and content.

- Promoting sustainability in tourism programs and when communicating with potential customers.

- Operating the travel agents business in a socially and environmentally friendly manners.

- Using new mediators with marketing and language skills in conducting direct contracts with tour operators, tourism offices and travel agents abroad.

- improving the quality of the services provided Continuously.

- Increasing interest in knowing clients' desires and preferences, and attempting to achieve them.

\section{a better financial performance, Promote} travelers' awareness, and support the environmental social responsibility of the agent. That's can be achieving through special "ecofriendly", "environmentally-friendly", or "green" programs which are considered as a marketing terms refer to programs that can enhance environmental sustainability, especially in destinations that is regarded as a green destination as Sharm El-sheikh which is designed to serve as a model of green transformation in Egypt. That is because Global green and ecotourism market is growing faster, and this is mainly driven by shifting consumer demand towards environmentally sustainable vacations. Some travel agents indicate that international tour operators giving marketing preference to environmentally sustainable destinations (e.g. TUI and Thomas Cook).

- Supporting new tourism trends as wedding tourism city tourism, culinary tourism, etc.

- Presenting new tourism programs as integrated tourism programs which support different tourism trends (cultural, rural and environment tourism within specific destination, in one program.

Another new tourism programs is special events programs which presents a new and attractive experience for tourists. Egyptian travel agents can create a new kind of programs through the re-enactment of the historical events and festivals that took place in the city that the itinerary designed for, in different historical periods. For example: Luxor (Thebes) owns two main ancient festivals. The Opet Festival which begins at October 29 and last to November 24, and the Beautiful festival of the valley which took place in June 8-9. Moreover, other minor and important festivals in and outside Thebes could be revived to form a festival calendar covering all over the year.

Based on the previous insights from the four action frame work, drawing the agent 'To Be' strategy canvas, is considered the third step in applying the BOS. This new value curve is related to the focus of certain agent on certain value which will distinguish it from the competitors in the industry. Table (6) indicates the results of the new competitiveness factors in the studied agents after applying BOS elements depending on the participants' points of view. Figure (3) represents the possible BOS move through "To Be" Strategy Canvas.

Table 6: Preliminary research results of the studied travel agents competitiveness factors After applying BOS elements

\begin{tabular}{|l|c|}
\hline \multicolumn{1}{|c|}{ competitiveness factors } & Percentage of agreements \\
\hline 1. Program cost reduction & $2 \%$ \\
\hline 2. Total program price reduction & $4 \%$ \\
\hline 3. Increase service quality & $83 \%$ \\
\hline 4. Differentiate programs & $93 \%$ \\
\hline 5. Differentiate segmentations & $30 \%$ \\
\hline 6. Differentiate marketing tools & $87 \%$ \\
\hline 7. Focus on special programs and segments & $93 \%$ \\
\hline
\end{tabular}


International Journal of Heritage, Tourism and Hospitality Vol. (12), No. (2/2), September, 2018 By: Faculty of Tourism and Hotels, Fayoum University, Egypt

Figure 3: "To Be" Strategy Canvas for Egyptian travel agent

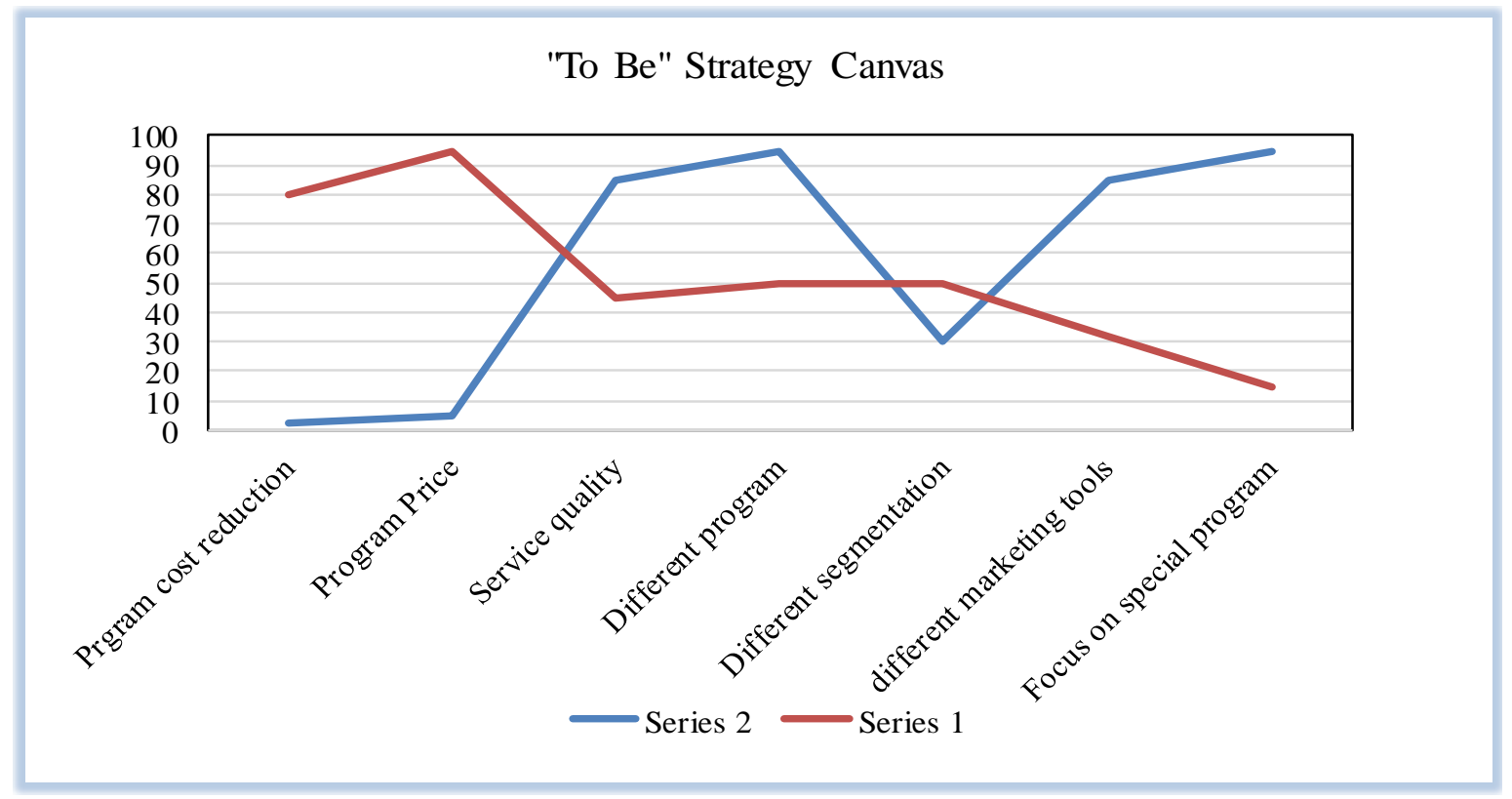

Second phase: The effect of BOS tools on marketing performance dimensions Descriptive statistic

Researchers analyze all items related to the independent variables (BOS elements) and dependent variables (marketing performance dimensions) descriptively by their means and standard deviations. Friedman Test -non-parametric statistical test involves ranking elements- also is applied to clarify priorities of applying the two variables among the selected travel agents.

Descriptive analysis of applying the BOS elements:

Table 7: Descriptive analysis of applying BOS in the Egyptian travel agents

\begin{tabular}{|c|c|c|c|c|c|}
\hline $\mathrm{S}$ & Independent variables & Mean & Std. Deviation & Level of agree & Friedman Test \\
\hline 1 & Eliminate elements: & 3.62 & 0.578 & Agree & 1.95 \\
\hline 2 & Reduce elements: & 3.33 & 0.947 & Neutral & 1.56 \\
\hline 3 & Raise elements: & 4.22 & 0.94 & Agree & 2.85 \\
\hline 4 & Create elements: & 4.22 & 0.794 & Agree & 3.46 \\
\hline & Total & 3.95 & .597 & Agree & 0.00 \\
\hline
\end{tabular}

This analysis was conducted to assess the travel agents managements' opinion regarding the BOS tools (Eliminate-Reduce-Raise-Create). The mean rank of all tools, ranged from (3.33) to (4.22) as shown in table (4). This indicates that travel agents have a good degree of agreement of applying BOS tools. As shown in table (7). The highest mean score of BOS tools are both the raise and the create elements $(\mathrm{M}=$ $4.22)$, followed by the eliminate elements $(M=3.62)$ and the reduce elements $(M=$ 3.33). According to the results of Friedman Test for priority among the BOS elements are: create, raise, reduce then, eliminate elements. These findings confirm the willingness of the travel agents to acquire new marketing strategies to create uncontested market space and attain tools for develop new competitive advantages.

Descriptive analysis of marketing performance dimensions:

Table 8: Descriptive analysis of marketing performance dimensions

\begin{tabular}{|c|c|c|c|c|c|}
\hline $\mathrm{S}$ & Dependent variables & Mean & Std. Deviation & Level of agree & Friedman Test \\
\hline 1 & Market share & 4.00 & 0.898 & Agree & 3.19 \\
\hline 2 & Customer satisfaction & 4.1 & 0.777 & Agree & 3.44 \\
\hline 3 & Customer loyalty & 3.05 & 0.589 & Neutral & 1.50 \\
\hline 4 & Innovation & 2.81 & 0.692 & Neutral & 1.88 \\
\hline & Total & 3.49 & .592 & Neutral & 0.00 \\
\hline
\end{tabular}


Table (8) show the dimensions that re used by the Egyptian travel agents to measure and develop its marketing performance. The results indicate that the most important dimensions are: customer satisfaction $(M=4.1)$, followed by the market share $(M=$ 4.00). The lowest mean score of the marketing performance dimensions are innovation $(M=2.81)$, followed by customer loyalty $(M=3.05)$. According to the results of Friedman Test for priority among the marketing performance measurement dimensions are: Market share, customer satisfaction, innovation then, customer loyalty. These findings reveal that Egyptian travel agents show negligence in both customer loyalty and innovation.

\section{Inferential statistic}

\section{Test of research hypothesis}

Regression results of BOS with marketing performance dimensions

Liner regression analysis was conducted to determine whether the independent variables (BOS) affect every dependent variables (marketing performance dimensions) or not and assess the degree of the influence.

Market share

Determining how well the model fits

Table 9: Regression model summary of market share

\begin{tabular}{|l|l|l|l|l|}
\hline Model & $\mathrm{R}$ & $\mathrm{R}$ Square & Adjusted R Square & Std. Error of the Estimate \\
\hline 1 & .969 & .939 & .938 & .219 \\
\hline \multicolumn{3}{|l|}{ a. Predictors: (Constant), total1 } \\
\hline \multicolumn{2}{|l}{ b. Dependent Variable: Market share } \\
\hline
\end{tabular}

Previous table provides $\mathrm{R}$ value $(\mathrm{R}$ correlation coefficient) $=0.969$ indicates that there is strong positive relationship between BOS and market share. $\mathrm{R}$ square value (coefficient of determination) $=0.939$ indicates that the independent variables (BOS elements) explain $94 \%$ of the variability of the dependent variable (market share) in the agency marketing performance.

Table 10: ANOVA analysis for BOS influencing market share

\begin{tabular}{|c|c|c|c|c|c|}
\hline Model & Sum of Squares & DF & Mean Square & $\mathrm{F}$ & Sig. \\
\hline Regression & 28.177 & 1 & 28.177 & 587.510 & $.000 \mathrm{a}$ \\
\hline Residual & 1.823 & 38 & .048 & & \\
\hline Total & 30.000 & 39 & & & \\
\hline
\end{tabular}

F- Ratio in the ANOVA table shows that the independent variables (BOS elements) statistically significantly predict the dependent variable (market share).

Estimated model coefficients

Table 11: BOS influencing market share

\begin{tabular}{|c|c|c|c|c|c|}
\hline \multirow{2}{*}{ Model } & \multicolumn{2}{|c|}{ Unstandardized Coefficients } & $\begin{array}{c}\text { Standardized } \\
\text { Coefficients }\end{array}$ & \multirow{2}{*}{$\mathrm{T}$} & \\
\cline { 2 - 4 } & $\mathrm{B}$ & Std. Error & Beta & $\mathrm{T}$ & Sig. \\
\hline (Constant) & 1.634 & .235 & & 6.952 & .000 \\
\cline { 6 - 7 } Total & 1.425 & .059 & .969 & 24.239 & .000 \\
\hline
\end{tabular}

Consider the effect of the BOS elements, the Unstandardized Coefficient B, for BOS $=1.634$. This means that for each 1 point increase in applying the BOS elements, there is 1.634 points increase in market share.

Customer satisfaction

Determining how well the model fits

Table: 12 Regression model summary of customer satisfaction

\begin{tabular}{|l|c|c|c|c|}
\hline Model & $\mathrm{R}$ & $\mathrm{R}$ Square & Adjusted R Square & Std. Error of the Estimate \\
\hline
\end{tabular}


International Journal of Heritage, Tourism and Hospitality Vol. (12), No. (2/2), September, 2018 By: Faculty of Tourism and Hotels, Fayoum University, Egypt

\begin{tabular}{|c|c|c|c|c|}
\hline 1 & .950 & .902 & .899 & .241 \\
\hline \multicolumn{5}{|c|}{ a. Predictors: (Constant), total1 } \\
\hline \multicolumn{5}{|c|}{ b. Dependent Variable: customer satisfaction } \\
\hline
\end{tabular}

Previous table provides $\mathrm{R}$ value (multiple correlation coefficient) $=0.950$ indicates that there is strong positive relationship between BOS and customer satisfaction. $\mathrm{R}$ square value (coefficient of determination) $=0.902$ indicates that the independent variables (BOS elements) explain $90.2 \%$ of the variability of the dependent variable (customer satisfaction) in the agency marketing performance.

Table 13: ANOVA analysis for BOS influencing customer satisfaction

\begin{tabular}{|l|l|c|c|c|c|c|}
\hline \multicolumn{2}{|c|}{ Model } & Sum of Squares & DF & Mean Square & F & Sig. \\
\hline \multirow{2}{*}{} & Regression & 20.385 & 1 & 20.385 & 349.747 & $.000 \mathrm{a}$ \\
\cline { 2 - 7 } & Residual & 2.215 & 38 & .058 & & \\
\cline { 2 - 7 } & Total & 22.600 & 39 & & & \\
\hline
\end{tabular}

F- Ratio in the ANOVA table shows that the independent variables (BOS elements) statistically significantly predict the dependent variable (customer satisfaction). Estimated model coefficients:

Table 14 : BOS influencing customer satisfaction

\begin{tabular}{|c|c|c|c|c|c|c|}
\hline \multirow{2}{*}{\multicolumn{2}{|c|}{ Model }} & \multicolumn{2}{|c|}{ Unstandardized Coefficients } & Standardized Coefficients & \multirow[t]{2}{*}{$\mathrm{T}$} & \multirow[t]{2}{*}{ Sig. } \\
\hline & & $\mathrm{B}$ & Std. Error & Beta & & \\
\hline \multirow[t]{2}{*}{1} & (Constant) & .692 & .259 & & $-2.670-$ & .011 \\
\hline & total1 & 1.212 & .065 & .950 & 18.702 & .000 \\
\hline
\end{tabular}

Consider the effect of the BOS elements, the Unstandardized Coefficient B, for BOS $=0.692$. This means that for each 1 point increase in applying the BOS elements, there is 0.692 points increase in customer satisfaction.

Customer loyalty

Determining how well the model fits

Table15: Regression model summary of customer loyalty

\begin{tabular}{|c|c|c|c|c|}
\hline Model & $\mathrm{R}$ & $\mathrm{R}$ Square & Adjusted R Square & Std. Error of the Estimate \\
\hline 1 & .419 & .175 & .177 & .579 \\
\hline \multicolumn{2}{|l}{ a. Predictors: (Constant), total1 } \\
\multicolumn{2}{|l}{ b. Dependent Variable: customer loyalty } \\
\hline
\end{tabular}

Previous table provides $\mathrm{R}$ value (multiple correlation coefficient) $=0.419$ indicates that there is positive relationship between BOS and customer loyalty. R square value (coefficient of determination) $=0.175$ indicates that the independent variables (BOS elements) explain $17.5 \%$ of the variability of the dependent variable (customer loyalty) in the agency marketing performance. These results shed light that there are different elements that can build and support travel agents customer loyalty. Some of the sampled participants pointed out that travel agents can pay attention to some activities that may enhance its customer loyalty besides its marketing strategies, as personalizing its services, establishing a close relationship with its customer and acknowledging loyal clients in different ways as offering creative loyal programs.

Table 16: ANOVA analysis for BOS influencing customer loyalty

\begin{tabular}{|l|l|r|r|r|r|r|}
\hline \multicolumn{1}{|l|}{ Model } & Sum of Squares & \multicolumn{1}{c|}{ DF } & Mean Square & F & Sig. \\
\hline \multirow{3}{*}{1} & Regression & .182 & 1 & .182 & .545 & $.465 \mathrm{a}$ \\
\cline { 2 - 7 } & Residual & 12.718 & 38 & .335 & & \\
\cline { 2 - 7 } & Total & 12.900 & 39 & & & \\
\hline \multicolumn{2}{|l|}{ a. Predictors: (Constant), total1 } \\
\hline
\end{tabular}

F- Ratio in the ANOVA table shows that the independent variables (BOS elements) statistically significantly predict the dependent variable (customer loyalty). 
International Journal of Heritage, Tourism and Hospitality Vol. (12), No. (2/2), September, 2018 By: Faculty of Tourism and Hotels, Fayoum University, Egypt

Estimated model coefficients

Table 17: BOS influencing customer loyalty

\begin{tabular}{|c|c|c|c|c|c|c|}
\hline \multicolumn{2}{|c|}{ Model } & \multicolumn{2}{|c|}{ Unstandardized Coefficients } & \multirow{2}{*}{$\begin{array}{c}\text { Standardized } \\
\text { Coefficients }\end{array}$} & \multirow[t]{2}{*}{$\mathrm{T}$} & \multirow[t]{2}{*}{ Sig. } \\
\hline & & B & Std. Error & & & \\
\hline \multirow[t]{2}{*}{1} & (Constant) & 2.597 & .621 & & 4.183 & .000 \\
\hline & total1 & .115 & .155 & .119 & .738 & .465 \\
\hline
\end{tabular}

a. Dependent Variable: customer loyalty

Consider the effect of the BOS elements, the Unstandardized Coefficient B, for BOS $=2.597$. This means that for each 1 point increase in applying the BOS elements, there is 2.597 points increase in customer loyalty.

\section{Innovation}

Determining how well the model fits

Table 18: Regression model summary of innovation

\begin{tabular}{|l|c|c|c|c|}
\hline Model & $\mathrm{R}$ & $\mathrm{R}$ Square & Adjusted R Square & Std. Error of the Estimate \\
\hline 1 & .755 & .570 & .558 & .396 \\
\hline \multicolumn{5}{|l}{ a. Predictors: (Constant), total1 } \\
\hline \multicolumn{4}{|l}{ b. Dependent Variable: innovation } \\
\hline
\end{tabular}

Previous table provides $\mathrm{R}$ value (multiple correlation coefficient) $=0.755$ indicates that there is positive relationship between BOS and innovation. $\mathrm{R}$ square value (coefficient of determination) $=0.570$ indicates that the independent variables (BOS elements) explain $57 \%$ of the variability of the dependent variable (innovation) in the agency marketing performance.

Table 19: ANOVA analysis for BOS influencing innovation

\begin{tabular}{|l|l|r|r|r|r|r|}
\hline \multicolumn{1}{|l|}{ Model } & Sum of Squares & \multicolumn{1}{c|}{ DF } & Mean Square & F & Sig. \\
\hline \multirow{3}{*}{1} & Regression & 7.884 & 1 & 7.884 & 50.273 & $.000 \mathrm{a}$ \\
\cline { 2 - 7 } & Residual & 5.959 & 38 & .157 & & \\
\cline { 2 - 7 } & Total & 13.844 & 39 & & & \\
\hline \multicolumn{2}{|l}{ a. Predictors: (Constant), total1 } \\
\hline
\end{tabular}

F- Ratio in the ANOVA table shows that the independent variables (BOS elements) statistically significantly predict the dependent variable (customer loyalty)

Estimated model coefficients

Table 20: BOS influencing innovation

\begin{tabular}{|c|c|c|c|c|c|c|}
\hline \multirow{2}{*}{\multicolumn{2}{|c|}{ Model }} & \multicolumn{2}{|c|}{$\begin{array}{c}\text { Unstandardized } \\
\text { Coefficients }\end{array}$} & \multirow{2}{*}{$\begin{array}{l}\text { Standardized } \\
\text { Coefficients } \\
\text { Beta }\end{array}$} & \multirow[t]{2}{*}{$\mathrm{T}$} & \multirow[t]{2}{*}{ Sig. } \\
\hline & & B & Std. Error & & & \\
\hline 1 & $\begin{array}{l}\text { (Constant) } \\
\text { total1 }\end{array}$ & $\begin{array}{l}.167 \\
.754\end{array}$ & $\begin{array}{l}.425 \\
.106\end{array}$ & .755 & $\begin{array}{r}394 \\
7.090\end{array}$ & $\begin{array}{l}.696 \\
.000\end{array}$ \\
\hline
\end{tabular}

Consider the effect of the BOS elements, the Unstandardized Coefficient B, for BOS $=0.167$. This means that for each 1 point increase in applying the BOS elements, there is 0.167 points increase in innovation.

\section{Discussion}

The previous results have certified that the research hypothesis which predicted that BOS would have a positive effect on travel agents marketing performance is supported. The regression analysis was used to assess the degree of the influence of applying BOS tools on the four marketing performance dimensions. Concerning the first dimension of marketing performance: market share, it was found to be positively influenced by BOS tools (B.939 . P- 0.00). The present finding concurs with other studies (e.g. Kim and Mauborgne, 2004, 2005a, 2005b; Layton, 2005; Srinivasan, 
2006; Buchness ,2015; Papazov and Mihaylova ,2016). Researches in these studies prove that blue ocean strategy is considered a new marketing strategy for organizations to create uncontested market in which competition irrelevant. In dimension of customer satisfaction, which is important because it provides marketers with a metric that they can use to measure and develop their marketing activities, it was also found to be positively affected by BOS (B =.692, P- 0.00). In this regard, several researchers (e.g. kim \& mauborgne, 2005; Sheehan and Vaidyanathan, 2009 ; Yang and Dylan,2011) found a positive relationship between BOS and customer satisfaction. They reported that value innovation is the base on which blue ocean are built to achieve customers satisfaction. As regards to the dimension of customer loyalty, it was also found to be positively affected by BOS (B = 2.597, P- 0.00). This result concurs with Bsri et al., (2011) who stated that the application of the 'eliminate-reduce-rise-create grid' increase customer loyalty. On the other hand, some of the sampled participants pointed out that travel agents can support its customer loyalty besides its marketing strategies through personalizing its services, establishing a close relationship with its customer and acknowledging loyal clients in different ways as offering creative loyal programs. Regarding the last dimension of marketing performance: innovation, the results indicates that it is also positively influenced by BOS $(\mathrm{B}=.167, \mathrm{P}-0.00)$. This finding is consistent with the results of previous researches (e.g. kim \& mauborgne, 2005; Petri et al., 2008 ; kang and li, 2013).

\section{Recommendations}

- Different tourism organizations should consider the integrity of the analytical tool existed in the BOS, consult with tourism experts to adopt the BOS, perform analysis to evaluate the feasibility of implementing BOS and decide whether it my adopt BOS or not, like SWOT analysis (Strengths, Weakness, Opportunity, Threats).

- Recommending the implementation of the BOS in the Egyptian travel agents that are interested in increasing their marketing performance for its great appeal in the present competitive business world.

- Qualifying the staff to use BOS tools through its proper scientific application, to get relief of avowing being trapped in old markets.

- Travel agents management need to focus on building customer loyalty, attracting new customers, understand market creation, stop focusing on price based competition, and worry less about segmentation.

- The need to change the concept of concentrating on Reduce or Raise strategies to face the crises experienced by the tourism markets only, as these dimensions should be used with the other BOS dimensions to work in normal circumstances and not only exceptional ones to find blue oceans and search for new demand away from competition.

- The need for all departments in travel agents to focus on the Innovation as one of the basic dimensions of the BOS, as it is one of the most important factors that help in creating new market spaces that were not reached before, where the field study showed negligence in the Innovation dimension in travel agents.

The following table shows a proposed action plan prepared by the researchers to implement the recommendations of the study in tourism companies:

\begin{tabular}{|c|c|c|}
\hline S & \multicolumn{1}{|c|}{ Recommendation } & \multicolumn{1}{|c|}{ Application Tools } \\
\hline 1 & Discussing the importance of the BOS. & $\begin{array}{l}- \text { Holding meetings with Heads of different } \\
\text { departments to present the new strategy. } \\
\end{array}$ \\
- Holding training meetings with specialists and \\
\hline
\end{tabular}


International Journal of Heritage, Tourism and Hospitality Vol. (12), No. (2/2), September, 2018 By: Faculty of Tourism and Hotels, Fayoum University, Egypt

\begin{tabular}{|c|l|l|}
\hline 2 & $\begin{array}{l}\text { Applying the BOS tools to create } \\
\text { uncontested market in which } \\
\text { competition irrelevant }\end{array}$ & $\begin{array}{l}\text { Heads of departments to identify mechanisms for } \\
\text { implementing the strategy. }\end{array}$ \\
\hline 3 & $\begin{array}{l}\text { Setting training programs for staff in } \\
\text { company's annual strategic plan. } \\
\text { - Informing the different departments with the new } \\
\text { strategy to be included in their plans. }\end{array}$ \\
$\begin{array}{l}\text { Marketing, Sales and Tour Operator } \\
\text { Departments inside the travel agent who } \\
\text { are unfamiliar with the concept. }\end{array}$ & $\begin{array}{l}\text { - Defining the BOS as a strategy to rebuild the market } \\
\text { borders and eliminate competition to employees, } \\
\text { especially in the Marketing and Sales Departments. } \\
\text { Setting a training program for the employees, } \\
\text { explaining the strategy's dimensions and holding } \\
\text { brainstorming sessions to come up with new ideas. }\end{array}$ \\
\hline
\end{tabular}

\section{References}

Alam, Samsul and Islam, Mohammad (2017). Impact of Blue Ocean Strategy on Organizational Performance: A Literature Review Towards Implementation Logic, IOSR Journal of Business and Management, Vol. 19 (1), Pp.01-19

Alghamdi, Abdulraheem (2016). Market Knowledge, Blue Ocean Strategy, and Competitive Advantage (Direct and indirect relationships and impact), Universal Journal of Management, Vol. 4, Pp. 141 - 160

Alonso-Almeida, M. and Bremser, K. (2013). Strategic Responses of the Spanish Hospitality Sector to the Financial Crisis, International Journal of Hospitality Management, Vol.32(1), Pp.141-148.

Basri, Jamilah , Gahdzali Mohd, and Ismail, Mohd (2011). Blue Ocean Strategy application in University Sains Malaysia library. Available online:

https://www.researchgate.net/publication/258499331_blue_ocean_strategy_applicatio n_in_universiti_sains_malaysia_library

Brady, J., R. (2005). W. Chan Kim and Mauborgne's Blue Ocean Strategy: How to Create Uncontested Market Space and Make the Competition Irrelevant, Harvard Business Press, UK.

Braganca, Ricardo (2016). Blue Ocean Strategy for Higher Education, International Conference ITS, ICE Tech and STE 2016. Available online: http://archive.org/details/ERIC ED571593

Bruni, A. , Cassia, F., and Magno, F. (2017). Marketing Performance Measurement in Hotels, Travel Agencies And Tour Operators: A Study of Current Practices, Current Issues in Tourism, Vol.20, Pp. 339-345

Buchness, Jennifer A., (2015). A Blue Ocean Strategy for the American Symphony Orchestra, Master Of Science In Organizational Dynamics Theses, School Of Arts And Science, University Of Pennsylvania, U.S.A Available online: http://repository.upenn.edu/od_theses_msod/76

Burke, Andrew, Van Stel, André, and Thurik, Roy (2016). Testing the Validity of Blue Ocean. Strategy Versus Competitivestrategy: An Analysis of the Retail Industry, International Review Of Entrepreneurship, Vol.12( 2), Pp.123-146

Butler, Colin (2008). Planning with Blue Ocean Strategy in the United Arab Emirates, International Journal Of Strategic Change: Briefings in Entrepreneurial Finance , Vol. 17, Pp.169-178

Fawzy, Nancy and Qoura, Omar (2016). Niche Market and Product Customization: Approaches to Increase the Arab Tourist Arrivals to Egypt: A Study of Hotels and Travel Agents, Journal of Faculty of Tourism and Hotels, Fayoum University, vol. 10 (2/2),Pp.343-358 
Homburg, C., Artz, M., and Wieseke, J. (2012). Marketing Performance Measurement Systems: Does Comprehensiveness Really Improve Performance? Journal of Marketing, Vol.76(3), Pp. 56-77

Huang, L. (2013). Building A Barrier-to-Imitation Strategy Model in the Travel Agency Industry, Current Issues in Tourism, Vol.16(4), Pp.313-326

Jaakko Aspara , Joel Hietanen, Petri Parvinen, and Henrikki Tikkanen (2008). An Exploratory Empirical Verification of Blue Ocean Strategies: Findings from Sales Strategy, Eighth International Business Research (IBR) Conference, Dubai, United Arab Emirates, 27-28 March, 2008. Available online: https://www.researchgate.net/publication/228461874

Jedil, Zahra , Zade, Hassan, and Rahmani, Zeinol (2015), The Blue Ocean Strategy In Insurance Industry (Case Study: Sina Insurance Company), Indian Journal Of Fundamental and Applied Life Sciences, Vol.5, Pp. 1434-1439

Jussani, Ailton, Viveiros, Patricia, and Edison, Fernandes (2010). Reflectinons on Blue Ocean Strategy: A Comparison with Ansoff's, Porter's, and Hax and Wilde's Strategies, Future Studies Research Journal, Trends and Strategies, Vol. 2( 2), Pp.17-35

Kabukin, D. (2014). Reviewing the Blue Ocean Strategy: Is the Blue Ocean Strategy Valid and Reliable? Master Thesis, University of Twente, Netherland.

Kang, Shihan and Li Duanyang (2013). Blue Ocean Strategic Planning of Acupuncture Clinics, Business in Copenhagen-Adapt, Jiankang Clinic as a Case Study, Master Thesis in Economic and Business Administration, Karlstad Business School ,Roskilde University, Sweden

Kim W. Chan, and Mauborgne Renée (2017). Blue Ocean Shift: Beyond Competing: Proven Steps to Inspire Confidence and Seize, Hachette Books, New York, U.S.A.

Kim W. Chan, and Mauborgne Renée (2004). Blue Ocean Strategy, Harvard Business Review, Vol. 82, Pp. 76-84.

Kim W. Chan, and Mauborgne Renée (2005a). Blue Ocean Strategy: From Theory to Practice, California Management Review, Vol. 47 (3), Pp. 21-105

Kim W. Chan, and Mauborgne Renée (2005b). Blue Ocean Strategy: How to Create Uncontested Market Space and Make the Competition Irrelevant, Harvard Business School Press, Boston, MA.

Kim W. Chan, and Mauborgne Renée (2005c). Value Innovation: A leap into the Blue Ocean, Journal of Business Strategy, Vol. 26 (4), Pp. 8-22

Kim, C., Yang , K.H., and Kim, J. (2007). A Strategy for Third-Party Logistics Systems: A Case Analysis Using the Blue Ocean Strategy, Omega, Vol. 36(4), Pp. 34-522

Kim, W.Chan , Mauborgne, Renée, and Ling, K. (2009). How to Implement Blue Ocean Strategy, Harvard Business Review Case Collection.

Konar, Rupam and Kumar, Jeetch (2016). Do the Traditional Travel Agents have any Future? An Empirical Analysis of Indonesian Travelers' Attitude, 15th. Asia Pacific Forum for Graduate Students Research in Tourism, Taylor's University, Malaysia. Available Online At: http://www.researchgate.net/publication/ $\underline{303434192}$

Kumar, Satheesh (2008). Blue Ocean Strategy: How to Create Uncontested Market Space and Make the Competition Irrelevant, South Asian Journal of Management, Vol. 15(2), Pp.121-135

Li, Xinyi (2018). Implementation of The Blue Ocean Strategy on Tourism Companies in Zhoushan Archipelago, International Conferences on Management, 
Economics, Education and Social Sciences (MEESS 2018), Advances in Social Sciences, Education and Huminities Research, Vol. 236, Pp. 139 - 142

Mintz, O. \& Currim, I. (2013), What Drives Managerial Use of Marketing and Financial Metrics and Does Metric Use Affect Performance of Marketing-Mix Activities? Journal of Marketing, Vol.77(2), Pp.17-40

Motley, L.B. (2008), Finding Your Bank's Blue Ocean Strategy, ABA Bank Marketing, Vol. 40(4), Pp.44-45

Okechukwu, Elizabeth, Ekwochi, Eucharia, and Eze, Jude (2018). Effect of Blue Ocean Strategy on the Performance of Telecommunication Firms in South East Nigeria, European Journal of Business and Management,Vol.,10 (21), Pp.48-56

Papazov, Emil and Mihaylova, Lyudmila (2016). Using key 'Blue Ocean' Tools for Strategy Rethinking of a SME: A Case from the Bulgarian Knitwear Industry, Journal of Economics and Business, Vol. 29(1), Pp. 104-110

Petri, Parvinen , Jaakko, Aspara , Hietanen, Joel, and Kajalo Sami (2011), Awareness, Action and Context-Specificity of Blue Ocean Practices in Sales Management, Journal of Management Decision, Vol. 49(8), Pp. 1218-1235.

Porter, Michael E. (1980). Competitive Strategy, Free Press, UK.

Savage, C. and Brommels, M. (2008). Innovation in Medical Education: How Linkoping Created a Blue Ocean for Medical Education in Sweden. Medical Teacher, Vol.30(5), Pp. 501-508

Sheehan, N.T. and Vaidyanathan G. (2009). Using a Value Creation Compass to Discover Blue Ocean, Strategy and Leadership, Vol. 37 (2), Pp. 13-20

Srinivasan, S.K (2006). Blue Ocean Strategy: How to Create Uncontested Market Space and Make the Competition Irrelevant, Journal for Decision Makers, Vol.31, Pp.151-156

Wanless, T. (2009). The Accidental Innovator, BC Business Magazine. Available online: ttps://www.bcbusiness.ca/the-accidental-innovator.

WWW.travelife.com / (last accessed 15/8/2018)

Yang, Ching-Chow, and Dylan Sung (2011). An Integrated Model of Value Creation Based on the Refined Kano's Model and the Blue Ocean Strategy, Total Quality Management \& Business Excellence, Special Issue: From Value Creation to Customer Satisfaction. Vol. 22(9) Pp. 925-940.

Yuhui, Gao (2010). Measuring Marketing Performance: A Review and a Framework, The Marketing Review, Vol. 10, Pp. 25-40.

Yang, J.T. (2012). Thinking Outside the Hotel Box: Blue Ocean Strategies for Hotels in Taiwan, Strategic Direction, Vol. 28(10), Pp.9-11

Yilmaz, Y. \& Bititci, U. (2006). Performance Measurement in the Value Chain: Manufacturing V. Tourism, International Journal of Productivity and Performance Management, Vol.55(5), Pp. 371-389.

Zahri, Mohd , Ahmat, Nur Hidayah, and Radzi Saleh (2015). Blue Ocean Strategies in Hotel Industry, Theory and Practice in Hospitality and Tourism Research Proceedings of the 2nd. International hospitality and tourism conference 2014 in Penang- Malaysia, Taylor \& Francis Group, London, U.K.

Zhao, Wang and Jinwei, Yang (2011). Application of Blue Ocean Strategy to Chinese 3G Mobile Telecom Industry, Thesis Of Master Of Science In Business Administration, Blekinge Inistitute of Technology, Sweden 